\title{
Acid Citrus Fruit Improvement via Interploid Hybridization Using Allotetraploid Somatic Hybrid and Autotetraploid Breeding Parents
}

\author{
Zenaida Viloria \\ La Universidad del Zulia, Departamento Botanica, Maracaibo, Edo. Zulia, Republica Bolivariana de \\ Venezuela $4005 Z U$ \\ Jude W. Grosser ${ }^{1}$ \\ Department of Horticulture, University of Florida, IFAS, Citrus Research andEducation Center (CREC), \\ 700 Experiment Station Road, Lake Alfred, FL 33850
}

\begin{abstract}
Additional Index words. cold-hardiness, embryo rescue, disease resistance, lemon, lime, seedlessness, triploid
Abstract. Interploid hybridization was conducted using 'Key' lime [Citrus aurantifolia (Cristm.) Swing.], 'Lakeland' limequat hybrid [C. aurantifolia $\times$ Fortunella japonica (Thumb.) Swing.], Palestine sweet lime (C. limettioides Tan.), 'Etrog' citron (C. medica L.), and seven lemon [C. limon (L.) Burm. F.] varieties as female progenitors and five allotetraploid somatic hybrids $\{$ 'Hamlin' sweet orange [C. sinensis $(\mathrm{L}$.$) Osbeck] × 'Femminello' lemon (C$. limon)]; 'Key' lime $\times$ 'Valencia' sweet orange $(C$. sinensis); 'Valencia' sweet orange $\times$ rough lemon $(C$. jambhiri Lush); Milam lemon (purported $C$. jambhiri hybrid) $\times$ 'Femminello' lemon $(C$. limon); and 'Valencia' sweet orange $\times$ 'Femminello' lemon\} and two autotetraploids ['Giant $\mathrm{Key}$ ' lime $(C$. aurantifolia) and 'Femminello' lemon] as pollen progenitors. A few tetraploid $\times$ diploid crosses were also performed. Thirty-five parental cross combinations were accomplished in 2000 , 2001, and 2002. The breeding targets were seedlessness, cold-tolerance, and disease resistance. Triploid hybrids were recovered through embryo culture. Generation of triploid citrus hybrids was affected by several factors including sexual compatibility, cross direction, embryo developmental stage, pollen viability, as well as horticultural practices and climatic conditions. Efficiency of triploid hybrid production was higher in diploid $\times$ tetraploid crosses than the reciprocal. Many more triploid hybrids were generated from lemon seed progenitors compared to the other acid citrus fruit progenitors. 'Todo el Año', 'Lisbon', and 'Limonero Fino 49' showed the highest sexual compatibility. Embryo germination rate and normal plant recovery were also higher in lemons as compared to the other seed progenitors. Low winter temperatures might have affected the hybrid production efficiency from tropical acid fruit progenitors. A total of 650 hybrids (mostly triploid) were transferred to soil. The novel genetic combinations of these progenies should be valuable for the genetic improvement of acid citrus fruit (lemons and limes).
\end{abstract}

Commercial acid citrus fruits are primarily represented by lemon and acid limes in world production. Lemon was identified as a hybrid of sour orange (Citrus aurantium L.) and citron $(C$. medica) through chloroplast and nuclear genome analysis (Gulsen and Roose, 2001). Citrus aurantifolia is considered a true acid lime, with small, spherical, and seedy fruit. The most common variety is 'Mexican' lime (also known as 'West Indian' or 'Key' lime). Molecular analysis suggested that citron and C. micrantha Wester. were its progenitors (Nicolosi et al., 2000). Citrus latifolia Tan. is also an acid lime, with larger spherical, seedless fruit. It is a triploid hybrid of unknown origin. 'Tahiti' or 'Persian' lime is the most commercially grown variety. 'Bearss' was initially considered a variety of 'Tahiti' lime, but it did not differ sufficiently from 'Tahiti' lime to be considered a new variety.

Both lemon and limes require different climatic conditions for optimal production. Lemon is more adapted to subtropical conditions with low-humidity atmosphere; even so, most of the growing lemon areas are periodically exposed to freezes. Limes are tropical species that are generally grown in warm and humid

Received for publication 12 July 2004. Accepted for publication 28 Aug. 2004 This research was supported by the Florida Agricultural Experiment Station, and approved for publication as Journal Series no. R-09951. The authors thank Dr. Glenn Wright (Univ. of Arizona) for assistance with lemon crosses conducted in Arizona, and La Universidad del Zulia and CONICIT (Venezuela) for providing financial support for Dr. Viloria's PhD program at the Univ. of Florida. ${ }^{1}$ Corresponding author: Phone (863) 956-1151; Fax: (863) 956-4631; E-mail: jwg@crec.ufl.edu areas of the subtropics. Marketing of fresh acid citrus fruit establishes fruit color difference to facilitate the identification of the two groups-yellow for lemon and green for limes.

The worldwide acid citrus fruit industry requires new varieties not only to satisfy a fresh market that demands high quality seedless fruit with high acid content and the manufacturing industry that calls for high-quality juice and oil but also to develop other horticultural traits to minimize the more threatening citrus diseases such as asiatic citrus canker [Xanthomonas axonopodis pv. citri (Hasse) Vauterin et al.], mal secco fungus [Phoma tracheiphila (Petri) Kantsch. \& Gik.] citrus tristeza virus, and witches' broom disease of lime (Phytoplasma aurantifolia Zreik et al.) Furthermore, since lemon and lime are cold sensitive, improving cold hardiness is another important objective. In Florida, in addition to the unsuitable climatic conditions necessary to produce a highquality lemon, the Great Freeze of 1894-95 caused a shift in the purpose for lemon production. Frozen lemon concentrate became the primary product. As part of a search for new varieties, 200 lemon selections were planted in Florida in 1950 to evaluate their horticultural performance, considering yield of acid on a per acre basis and high grade of peel oil as the main targets. A few clones were selected as promising for processing (Knorr, 1958).

'Bearss' lemon and the hybrid 'Meyer' lemon (C.meyeri Tan.) are the current acid citrus fruit varieties that make up the small Florida lemon industry with a total of 1000 bearing acres in 2000 (Florida Dept. of Agriculture, 2001). The eradication program to control Asiatic citrus canker disease has devastated 'Key' and 
'Tahiti' lime production in southern Florida. The eradication program is still under way, with 3168 acres destroyed in 1996, and only 388 acres of limes remained at the end of 2002 (Florida Dept. of Agriculture, 2002).

In California, 'Eureka' $\times$ 'Lisbon' lemon crosses were unsuccessful. Inbreeding depression is characteristic of citrus hybrids from narrow crosses, while hybrid vigor is present in progenies from wider crosses (Soost and Roose, 1996). Under these circumstances, interploid hybridization becomes an interesting approach owing to the availability of a new somatic hybrid germplasm pool that combines together diverse genome combinations from citrus and citrus relatives (Grosser et al., 1998, 2000). Also, seedless fruit can be generated (via triploidy) to satisfy the fresh citrus market desires.

Interploid crosses, either diploid $\times$ tetraploid or the reciprocal, are being increasingly used in citrus to generate seedless hybrids (Cameron and Burnett, 1978; Cameron and Soost, 1969; Oiyama and Kobayashi, 1990; Roose and Williams, 2000; Starrantino, 1992; Tusa et al., 1996). Triploid recovery is to a large extent precluded by precocious endosperm development and polyembryony. Endosperm degeneration was evident 7-10 weeks after fertilization of monoembryonic seed parents in diploid $\times$ tetraploid crosses; in consequence, a high number of embryos failed to develop, reducing the frequency of viable triploid hybrid recovery. Higher proportions of triploid hybrids were generated from tetraploid $\times$ diploid crosses using monoembryonic seed progenitors (Cameron and Burnett, 1978).

The 3:5 ploidy ratio of embryo to endosperm also induced seed abortion in crosses using $4 \mathrm{X}$ females but embryo and endosperm developed normally in small seed (Esen and Soost, 1973). Similarly, 5X endosperm of polyembryonic seeds showed precocious development, regardless of the presence of nucellar embryos (Wakana et al., 1981). It was hypothesized that the unbalance of chromosome numbers between embryo and endosperm disturbs the relationship between them causing endosperm abortion and, subsequently, embryo failure (Esen and Soost, 1973). According to the endosperm balance number hypothesis, the 2 maternal : 1 paternal ratio in the hybrid endosperm itself determines the normal endosperm development (Carputo et al., 1999).

To increase triploid hybrid recovery, monoembryonic seed parents are recommended, since occurrence of nucellar embryos affects survival and normal development of zygotic embryos (Soares Filho et al., 1992). However, polyembryony is a trait present in most citrus species, including acid citrus fruit varieties. Nonetheless, the efficiency of hybrid recovery has improved owing to the application of the embryo culture technique. This study was performed to generate triploid progenies of acid citrus fruit through interploid hybridization. The ultimate goal is to produce acid lime- and lemon-type fruit with potential for seedlessness, and improved cold-tolerance and disease resistance. Several variables related to pollination and fertilization efficiency are discussed.

\section{Materials and Methods}

Plant material. Diploid $\times$ tetraploid crosses and some reciprocals were carried out during three successive years. During the 2000 season, the female breeding progenitors were the following diploids: 'Key' lime, 'Lakeland' limequat hybrid, Palestine sweet lime, 'Etrog' citron, and two lemon varieties, 'Lisbon' and 'Todo el Año'. Two allotetraploid somatic hybrids 'Hamlin' sweet orange $\times$ 'Femminello' lemon (HF) and 'Valencia' sweet orange $\times$ rough lemon (VRL) were also included as female parents. The pollen progenitors were the following three somatic hybrids: HF, 'Key' lime $\times$ 'Valencia' sweet orange (KLV), and Milam lemon $\times$ 'Femminello' lemon (MF), and two autotetraploids 'Giant Key' lime (GKL) and 4X 'Femminello' lemon (4XF). The diploids 'Lakeland' limequat hybrid and 'Key' lime were also used as pollen progenitors.

In the 2001 season, five lemon varieties grown at the University of Arizona were added to the previous group of seed progenitors as follows: 'Limoneria 8A Lisbon', 'Limonero fino 49', 'Femminello Santa Teresa', 'Arancino', and 'Genova'. Additionally, 'Valencia' sweet orange $\times$ 'Femminello' (VF) somatic hybrid was utilized as seed and pollen progenitors, and VRL was pollen progenitor as well. During the 2002 season, two interploid crosses were performed: 'Lisbon' $\times$ HF and 'Todo el Año' $\times$ HF. The Florida Citrus Arboretum-Division of Plant Industry (Winter Haven), Univ. of Florida-IFAS-Citrus Research and Education Center (Lake Alfred), and Orie Lee Groves (St. Cloud, Fla.) were the field locations where most of the breeding progenitors were grown, unless otherwise stated.

Pollination. Flower buds from pollen parents were collected when they were close to anthesis. Excised anthers were placed into petri plates to be dehydrated over anhydrous calcium sulfate desiccant (Drierite Co., Hammond, Wash.) overnight. Dry pollen was kept at $4{ }^{\circ} \mathrm{C}$ until use. Viability of dry pollen grains was determined using acetocarmine staining (1\%). Viable (red) and non-viable (yellow) pollen grains were counted on five microscope fields $(200 \times)$ from two slide samples per pollen progenitor.

Alternatively, flower buds from female parents were selected according to bud size and proximity to anthesis in order to maximize uniformity of the physiological age. After petal removal and emasculation, a portion of pollen was placed on the stigma. Flowers were tagged indicating pollen source, number of flowers, and date. Harvest dates varied according to seed progenitor and season, about 60-90 d after pollination for 'Key' lime and 'Lakeland' limequat and 90-110 d for the other progenitors.

SEED AND EMbryo EXTRACTION. Fruit were surface-sterilized by immersion in a solution of $20 \%$ commercial bleach $(5.3 \%$ $\mathrm{NaOCl}$ ) and 2-3 drops/L Tween 20 for at least $30 \mathrm{~min}$. Under aseptic conditions, dry fruits were cut at the equatorial zone avoiding the core where seeds are embedded. Both halves were twisted in opposite direction until total separation. Seeds were grouped according to size: small = small seed without endosperm remaining, medium = intermediate seed size with semi-solid or degenerated endosperm, and large = fully developed seed.

Embryos were carefully excised and categorized into three groups: globular, heart, and early cotyledonary embryos; immature cotyledonary embryos; and mature embryos. Embryo excision was performed under $100 \times$ magnification using a stereomicroscope. Excised embryos were immediately plated on different nutrient media to induce germination and further seedling development (Z. Viloria et al., unpublished). Fruit set, seed number/fruit, empty seed number, and number of embryos per developmental stage were recorded and analyzed in each cross combination.

Ploidy analysis. After culturing seedlings on RMAN medium (Grosser and Gmitter, 1990) or Murashige and Skoog medium (Murashige and Skoog, 1962) for 1 month, most of the plants were ready to be transferred to soil. Before soil transplant, ploidy level was determined by flow cytometry. A small piece of leaf sample and diploid standard (sweet orange) were chopped simultaneously in extraction buffer, after filtration with $20-\mu \mathrm{m}$ mesh; the nuclei were stained with fluorescent dye. Extraction buffer and staining solution were obtained from a Partec (Partec GMBH, 
Münster, Germany) high resolution staining kit. The relative amount of nuclear DNA content (C-value) was measured using a tabletop Partec ploidy analyzer (Fig. 1). The ploidy analyzer was standardized using a diploid sweet orange, the triploid 'Persian' lime, and a previously confirmed tetraploid somatic hybrid at the beginning of each usage. Ploidy analysis via flow cytometry is routine in our lab, and results have been published previously (Guo et al., 2004; Medina-Urrutia et al., 2004).

Polyploids were planted in 38-well trays containing a commercial soil mixture of Metro Mix 500 (The Scotts Co., Marysville, Ohio). Plants were covered with a plastic lid for 2 weeks and kept under partial shade for acclimatization. After 2 weeks, seedlings were fertilized with $2-3 \mathrm{~g} \cdot \mathrm{L}^{-1}$ Peters soluble fertilizer (20N-8.8P-16.6K with micronutrients; United Industries Corp., St. Louis), Minor elements were periodically supplied to old seedlings using Essential Minor Elements (Agricultural Insecticides, Palmetto, Fla.) and Osmocote (The Scotts Co.).

\section{Results}

Viability of dry pollen, estimated by acetocarmine staining, was high (46\% to 91\%) for most of the progenitors for both the 2000 and 2001 seasons, except for 'Key' lime (7.7\%) and KLV (25.3\%) from the 2000 seasons. Pollen of KLV even in fresh condition showed low viability (59.9\%). After the cold weather period, 'Key' lime and the 'Lakeland' limequat hybrid flowered continuously, with occasionally heavy blooming. In 2000, flowering began in February, while a 2-month delay was evident in 2001. The other female progenitors showed a flowering peak in March.

Fruit set of individual female progenitors was evidently affected by the pollen progenitors. In diploid $\times$ tetraploid crosses accomplished in 2000 (Tables 1 and 3), HF resulted in high percentages of fruit set on lemons, 'Lakeland' limequat, and Palestine sweet lime. In spite of the low pollen viability of KLV, fruit set ranged $26 \%$ to $33 \%$ for all female parents with the exception of 'Key' lime $(11.0 \%)$ and 'Lakeland' limequat (11.7\%). 'Key' lime as a seed progenitor experienced the lowest fruit set regardless of the pollen progenitor, while lemons and 'Etrog' citron set high

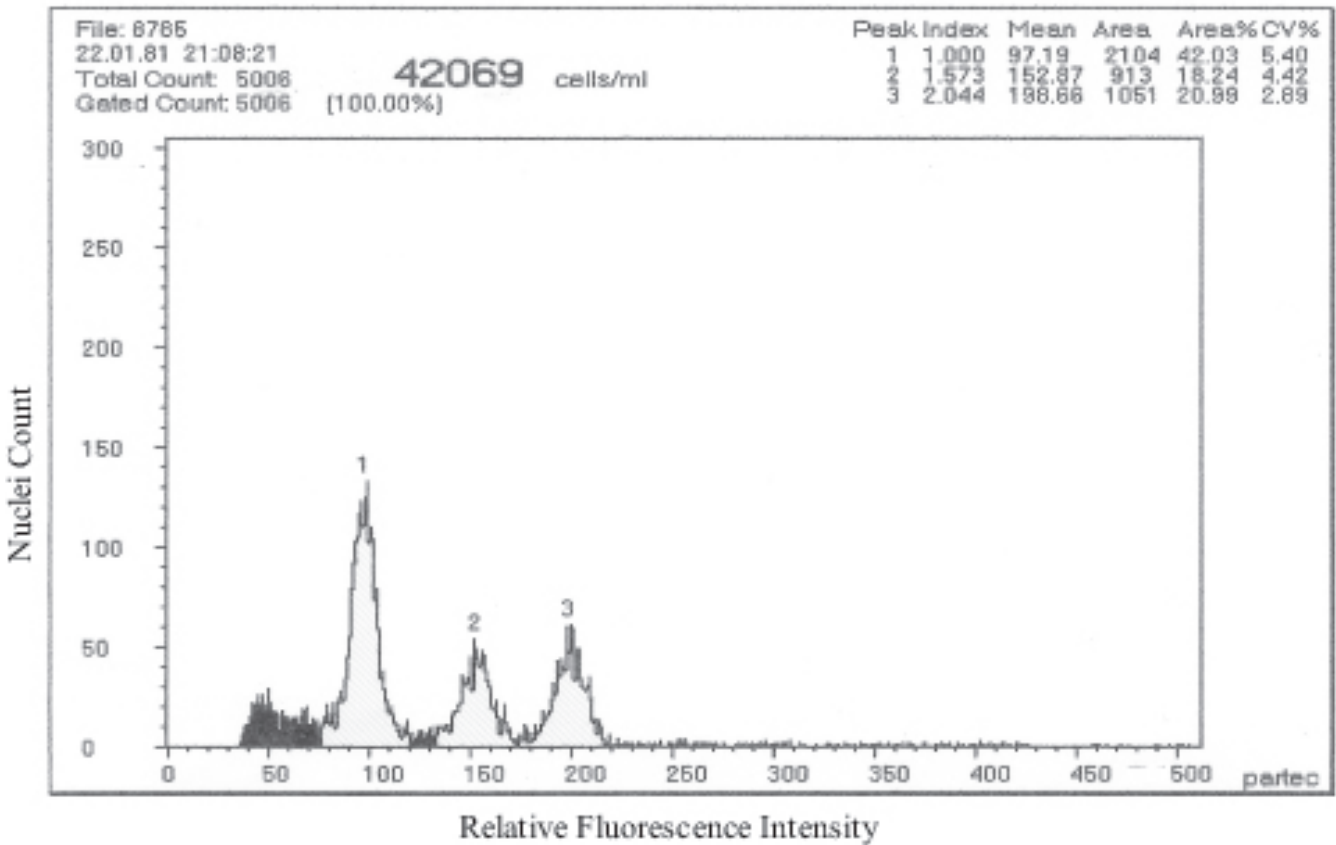

Fig. 1. Flow-cytometry analysis of nuclear DNA (C-value) of diploid sweet orange (peak 1), new triploid acid-fruit hybrid from an interploid cross (peak 2) and known tetraploid somatic hybrid (peak 3). percentages of fruit. Relating to seed number per fruit, only those highly seedy varieties, such as 'Lisbon' and 'Etrog', showed a noticeable variation of seed number depending upon the pollen progenitor. A high proportion of large seeds were obtained with 'Lakeland' limequat and 'Lisbon' lemon and some crosses with Palestine sweet lime. Quantity of empty seed was affected by pollen progenitor, particularly when using HF pollen, which appeared to induce more seeds and a notably larger proportion of empty seeds.

Usually, cross combination, embryo developmental stage, and nutrient media (data not presented) affected in vitro germination and normal plant recovery percentages. The less advanced the developmental stage the embryos exhibited at the time of plating, the lower the rates of subsequent germination and plant recovery. Small embryos from lemon seed parents germinated and developed into normal plants at higher rates than from the other acid citrus progenitors. Triploids were identified in all progenies from diploid $\times$ tetraploid crosses conducted during the 2000 season (Tables 2 and 4). Generally, a higher proportion of triploids developed from immature embryos; however, an exception was the triploids from mature cotyledonary embryos of 'Etrog' $\times$ KLV. Total number of triploids per seed progenitor was: 34 'Key' lime, 28 'Etrog', 32 'Lisbon', and 25 'Todo el Año'. Considering the triploid population regarding the total seed number per seed parent, the percentages were as follows: $8.9,8.7,6.0$, and 10.3 , respectively. Smaller numbers of triploids developed from 'Lakeland' limequat (9) and Palestine sweet lime (13), which corresponded to 3.3\% and $6.8 \%$ triploids of total extracted seed, respectively.

Analyzing the fertility of pollen parents, the triploid frequencies were similar for HF (6.7), KLV (6.8), and 4X Femminello (7.1) and very low for GKL (1.8). A few tetraploids were obtained from 'Key' lime, 'Lakeland' limequat, and 'Lisbon'lemon. A pentaploid was generated from HF $\times$ 'Lakeland' limequat and a hexaploid from $\mathrm{HF} \times$ Palestine sweet lime. To identify the origin of the tetraploids from 'Lakeland' limequat crosses, RAPD-PCR analysis was carried out among progenies and progenitors. Seven out of 24 random primers (decamer and twelve-mer primers) showed polymorphism between progenitors, but the DNA patterns of tetraploid plants were identical to the seed progenitor ('Lakeland'limequat), which indicates that they are autotetraploids that developed from nucellar tissue (data not presented).

The repeated cross combinations conducted during the 2001 season showed a similar tendency for the previously discussed variables (Tables 1 and $3)$. The fruit set of 'Key' lime showed a general improvement. Also, the recovery of large seed was reduced in 'Key' lime and 'Lakeland' limequat crosses. Palestine sweet lime produced a considerably lower fruit set in the second season; but this inconvenience was apparently associated with drought stress encountered by the nonirrigated seed trees used. An increment 
Table 1. Fruit set and number of seeds and embryos of acid citrus progenies obtained from diploid (non-lemon female progenitors) $\times$ tetraploid crosses conducted during the 2000 and 2001 seasons.

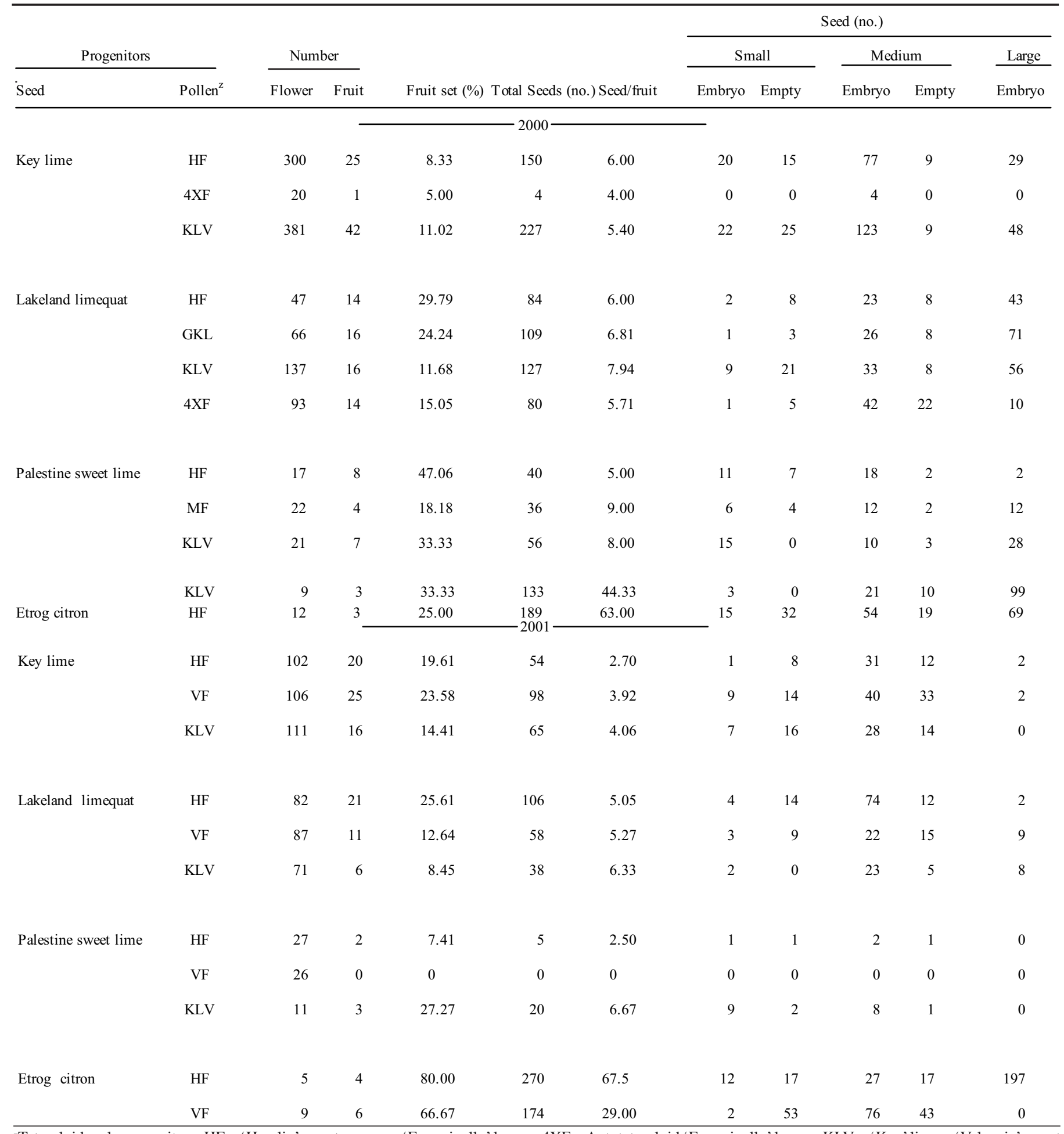

zTetraploid male progenitors: HF = 'Hamlin' sweet orange $\times$ 'Femminello' lemon; 4XF = Autotetraploid 'Femminello' lemon; KLV = 'Key' lime $\times$ 'Valencia' sweet orange; GKL = 'Giant Key' lime; MF = 'Milam' hybrid $\times$ 'Femminello' lemon; VF = 'Valencia' sweet orange $\times$ 'Femminello' lemon. 
Table 2. Plant recovery and ploidy level of acid citrus progenies generated from diploid (non-lemon female progenitors) $\times$ tetraploid crosses conducted during the 2000 and 2001 seasons.

\begin{tabular}{|c|c|c|c|c|c|c|c|c|c|c|c|c|c|c|c|c|}
\hline \multirow{2}{*}{\multicolumn{2}{|c|}{ Progenitors }} & \multicolumn{15}{|c|}{ Embryo Developmental Stage } \\
\hline & & \multicolumn{5}{|c|}{ Globular--Early Cotyledonary } & \multicolumn{5}{|c|}{ Large Immature Cotyledonary } & \multicolumn{5}{|c|}{ Mature Cotyledonary } \\
\hline Seed & Pollen $^{2}$ & $\% \mathrm{G}^{\mathrm{y}}$ & $\% \mathrm{NP}^{\mathrm{x}}$ & $2 X^{w}$ & $3 X^{v}$ & $4 X^{u}$ & $\% \mathrm{G}$ & $\% \mathrm{NP}$ & $2 \mathrm{X}$ & $3 \mathrm{X}$ & $4 \mathrm{X}$ & $\% \mathrm{G}$ & $\% \mathrm{NP}$ & $2 \mathrm{X}$ & $3 X$ & $4 X$ \\
\hline \multirow[t]{3}{*}{ Key lime } & $\mathrm{HF}$ & 75.51 & 46.15 & 36 & 6 & 0 & 100 & 60.20 & 49 & 10 & 0 & 72.50 & 89.02 & 71 & 2 & 0 \\
\hline & $4 \mathrm{XF}$ & 0 & 0 & 0 & 0 & 0 & 80.00 & 40.00 & 2 & 2 & 0 & 0 & 0 & 0 & 0 & 0 \\
\hline & KLV & 54.90 & 42.62 & 21 & 5 & 0 & 100 & 70.20 & 103 & 2 & 1 & 87.10 & 81.33 & 53 & 7 & 1 \\
\hline \multirow[t]{4}{*}{ Lakeland limequat } & $\mathrm{HF}$ & 35 & 55.56 & 3 & 2 & 0 & 0 & 0 & 0 & 0 & 0 & 97.78 & 100 & 69 & 2 & 0 \\
\hline & GKL & 66.67 & 28.57 & 2 & 0 & 0 & 0 & 0 & 0 & 0 & 0 & 97.67 & 85.48 & 103 & 2 & 1 \\
\hline & KLV & 36.00 & 28.57 & 2 & 2 & 0 & 100 & 50.00 & 9 & 0 & 0 & 100 & 80.92 & 104 & 1 & 1 \\
\hline & $4 \mathrm{XF}$ & 37.04 & 28.57 & 0 & 4 & 0 & 100 & 0 & 0 & 0 & 0 & 100 & 84.85 & 28 & 0 & 0 \\
\hline \multirow[t]{3}{*}{ Palestine sweet lime } & $\mathrm{HF}$ & 85.00 & 48.78 & 16 & 4 & 0 & 100 & 50.00 & 2 & 0 & 0 & 100 & 100 & 2 & 0 & 0 \\
\hline & MF & 62.50 & 62.5 & 2 & 3 & 0 & 100 & 71.43 & 15 & 0 & 0 & 100 & 76.32 & 29 & 0 & \\
\hline & KLV & 100 & 23.53 & 7 & 1 & 0 & 100 & 100 & 9 & 0 & 0 & 100 & 83.75 & 67 & 0 & 0 \\
\hline \multirow[t]{2}{*}{ Etrog citron } & $\mathrm{HF}$ & 42.86 & 60.00 & 1 & 8 & 0 & 0 & 0 & 0 & 0 & 0 & 95.77 & 83.78 & 61 & 1 & 0 \\
\hline & KLV & 75.00 & 8.70 & 0 & 2 & 0 & 0 & 0 & 0 & 0 & 0 & 90.53 & 68.63 & 53 & 17 & 0 \\
\hline \multirow[t]{3}{*}{ Key lime } & $\mathrm{HF}$ & 61.11 & 43.75 & 7 & 0 & 0 & 100 & 58.06 & 17 & 1 & 0 & 100 & 100 & 4 & 0 & 0 \\
\hline & $\mathrm{VF}$ & 81.18 & 100 & 13 & 4 & 0 & 100 & 93.55 & 26 & 2 & 1 & 100 & 100 & 10 & 0 & 0 \\
\hline & KLV & 60.87 & 38.46 & 8 & 2 & 0 & 83.33 & 43.24 & 12 & 3 & 0 & 100 & 100 & 3 & 0 & 0 \\
\hline \multirow[t]{3}{*}{ Lakeland limequat } & $\mathrm{HF}$ & 75.00 & 67.31 & 31 & 4 & 0 & 97.67 & 90.80 & 78 & 1 & 0 & 0 & 0 & 0 & 0 & 0 \\
\hline & $\mathrm{VF}$ & 94.44 & 45.16 & 23 & 3 & 1 & 100 & 95 & 19 & 0 & 0 & 100 & 88.89 & 31 & 0 & 1 \\
\hline & KLV & 65.00 & 36.67 & 7 & 4 & 0 & 88.00 & 76.47 & 7 & 4 & 0 & 100 & 100 & 8 & 0 & 0 \\
\hline \multirow[t]{2}{*}{ Etrog citron } & $\mathrm{HF}$ & 77.27 & 31.58 & 2 & 5 & 0 & 0 & 0 & 0 & 0 & 0 & 96.59 & 93.26 & 77 & 6 & 0 \\
\hline & $\mathrm{VF}$ & 100 & 62.5 & 10 & 0 & 0 & 95.16 & 93.22 & 59 & 0 & 0 & 0 & 0 & 0 & 0 & 0 \\
\hline \multirow[t]{2}{*}{ Palestine sweet lime } & $\mathrm{HF}$ & 66.67 & 40.00 & 2 & 0 & 0 & 0 & 0 & 0 & 0 & 0 & 0 & 0 & 0 & 0 & 0 \\
\hline & KLV & 83.33 & 87.5 & 16 & 5 & 0 & 100 & 90.91 & 9 & 1 & 0 & 0 & 0 & 0 & 0 & 0 \\
\hline
\end{tabular}


Table 3. Lemon fruit set, number of seeds and embryos obtained from diploid $\times$ tetraploid crosses completed in the 2000, 2001, and 2002 seasons.

\begin{tabular}{|c|c|c|c|c|c|c|c|c|c|c|c|}
\hline \multirow{2}{*}{\multicolumn{2}{|c|}{ Progenitors }} & & & \multirow[b]{3}{*}{ Fruit set (\%) } & \multirow{2}{*}{\multicolumn{2}{|c|}{ Number }} & \multicolumn{5}{|c|}{ Seed (no.) } \\
\hline & & \multicolumn{2}{|c|}{ Number } & & & & \multicolumn{2}{|c|}{ Small } & \multicolumn{2}{|c|}{ Medium } & \multirow{2}{*}{$\frac{\text { Large }}{\text { Embryo }}$} \\
\hline$\overline{\text { Seed }}$ & Pollen $^{z}$ & Flower & $\overline{\text { Fruit }}$ & & Total Seeds & $\overline{\text { Seeds/fruit }}$ & Embryo & Empty & Embryo & Empty & \\
\hline \multirow[t]{2}{*}{ Lisbon } & $\mathrm{HF}$ & 21 & 9 & 42.86 & 375 & 41.67 & 47 & 172 & 83 & 22 & 51 \\
\hline & KLV & 23 & 6 & 26.09 & 157 & 26.00 & 21 & 22 & 32 & 7 & 75 \\
\hline \multirow[t]{2}{*}{ Todo el Año } & $\mathrm{HF}$ & 11 & 9 & 81.82 & 147 & 16.33 & 4 & 56 & 40 & 16 & 31 \\
\hline & KLV & 20 & 6 & 30.00 & 97 & 16.17 & 15 & 26 & 26 & 17 & 13 \\
\hline \multirow[t]{3}{*}{ Todo el Año } & $\mathrm{HF}$ & 27 & 20 & 74.07 & 406 & 20.3 & 13 & 55 & 164 & 99 & 75 \\
\hline & $\mathrm{VF}$ & 16 & 10 & 62.50 & 157 & 15.7 & 8 & 36 & 56 & 47 & 10 \\
\hline & KLV & 29 & 15 & 51.72 & 281 & 18.73 & 11 & 19 & 118 & 39 & 94 \\
\hline \multirow[t]{2}{*}{ Lisbon } & $\mathrm{VF}$ & 9 & 7 & 77.77 & 199 & 28.43 & 3 & 70 & 40 & 35 & 51 \\
\hline & KLV & 8 & 3 & 37.50 & 160 & 53.33 & 15 & 78 & 52 & 6 & 9 \\
\hline \multirow[t]{4}{*}{ Limoneria 8A Lisbon } & $\mathrm{HF}$ & 15 & 8 & 53.33 & 125 & 15.63 & 0 & 33 & 44 & 32 & 16 \\
\hline & $\mathrm{VF}$ & 15 & 0 & 0 & 0 & 0 & 0 & 0 & 0 & 0 & 0 \\
\hline & KLV & 15 & 0 & 0 & 0 & 0 & 0 & 0 & 0 & 0 & 0 \\
\hline & VRL & 19 & 6 & 31.58 & 103 & 17.17 & 0 & 19 & 31 & 37 & 16 \\
\hline \multirow[t]{4}{*}{ Limonero Fino 49} & $\mathrm{HF}$ & 15 & 12 & 80.00 & 503 & 41.92 & 34 & 205 & 142 & 96 & 26 \\
\hline & VF & 20 & 0 & 0 & 0 & 0 & 0 & 0 & 0 & 0 & 0 \\
\hline & KLV & 15 & 7 & 46.67 & 140 & 20.00 & 2 & 45 & 42 & 49 & 2 \\
\hline & VRL & 15 & 7 & 46.67 & 268 & 38.29 & 15 & 94 & 55 & 92 & 12 \\
\hline \multirow[t]{3}{*}{ Femminello Santa Teresa } & $\mathrm{HF}$ & 15 & 5 & 33.33 & 83 & 16.60 & 0 & 8 & 47 & 18 & 10 \\
\hline & $\mathrm{VF}$ & 15 & 0 & 0 & 0 & 0 & 0 & 0 & 0 & 0 & 0 \\
\hline & KLV & 15 & 0 & 0 & 0 & 0 & 0 & 0 & 0 & 0 & 0 \\
\hline \multirow[t]{4}{*}{ Arancino } & $\mathrm{HF}$ & 16 & 4 & 25 & 0 & 0 & 0 & 0 & 0 & 0 & 0 \\
\hline & $\mathrm{VF}$ & 15 & 1 & 6.67 & 0 & 0 & 0 & 0 & 0 & 0 & 0 \\
\hline & KLV & 15 & 1 & 6.67 & 0 & 0 & 0 & 0 & 0 & 0 & 0 \\
\hline & VRL & 17 & 0 & 0 & 0 & 0 & 0 & 0 & 0 & 0 & 0 \\
\hline \multirow[t]{4}{*}{ Genova } & $\mathrm{HF}$ & 15 & 0 & 0 & 0 & 0 & 0 & 0 & 0 & 0 & 0 \\
\hline & $\mathrm{VF}$ & 15 & 0 & 0 & 0 & 0 & 0 & 0 & 0 & 0 & 0 \\
\hline & KLV & 15 & 0 & 0 & 0 & 0 & 0 & 0 & 0 & 0 & 0 \\
\hline & VRL & 15 & 1 & 6.67 & 22 & 22 & 3 & 3 & 13 & 0 & 3 \\
\hline Todo el Aňo & $\mathrm{HF}$ & 24 & 21 & 87.5 & 887 & 42.24 & 76 & 483 & 206 & 36 & 86 \\
\hline Lisbon & $\mathrm{HF}$ & 33 & 20 & 60.6 & 764 & 38.2 & 89 & 341 & 156 & 59 & 119 \\
\hline
\end{tabular}

zTetraploid male progenitors: HF $=$ 'Hamlin' sweet orange $\times$ 'Femminello' lemon; KLV = 'Key' lime $\times$ 'Valencia' sweet orange; VF $=$ 'Valencia' sweet orange $\times$ 'Femminello' lemon; VRL = 'Valencia' sweet orange $\times$ rough lemon. 
Table 4. Plant recovery and ploidy level of lemon progenies generated from diploid $\times$ tetraploid crosses conducted during the 2000 , 2001, and 2002 seasons.

\begin{tabular}{|c|c|c|c|c|c|c|c|c|c|c|c|c|c|c|c|c|}
\hline \multirow{2}{*}{\multicolumn{2}{|c|}{ Progenitors }} & \multicolumn{15}{|c|}{ Embryo Developmental Stage } \\
\hline & & \multicolumn{5}{|c|}{ Globular--Early Cotyledonary } & \multicolumn{5}{|c|}{ Large Immature Cotyledonary } & \multicolumn{5}{|c|}{ Mature Cotyledonary } \\
\hline Seed & Pollen ${ }^{z}$ & $\% \mathrm{G}^{\mathrm{y}}$ & $\% \mathrm{NP}^{\mathrm{x}}$ & $2 X^{w}$ & $3 X^{v}$ & $4 X^{u}$ & $\% \mathrm{G}$ & $\% \mathrm{NP}$ & $2 \mathrm{X}$ & $3 X$ & $4 \mathrm{X}$ & $\% \mathrm{G}$ & $\% \mathrm{NP}$ & $2 \mathrm{X}$ & $3 X$ & $4 \mathrm{X}$ \\
\hline \multirow[t]{2}{*}{ Lisbon } & $\mathrm{HF}$ & 43.52 & 64.81 & 16 & 19 & 0 & 60.00 & 50.00 & 3 & 1 & 0 & 96.83 & 68.06 & 45 & 4 & 2 \\
\hline & KLV & 45.10 & 41.94 & 7 & 6 & 0 & 0 & 0 & 0 & 0 & 0 & 94.44 & 61.54 & 46 & 2 & 0 \\
\hline \multirow[t]{2}{*}{ Todo el Aňo } & $\mathrm{HF}$ & 65.38 & 38.89 & 1 & 6 & 0 & 94.44 & 65.38 & 9 & 8 & 0 & 97.22 & 50.00 & 22 & 3 & 0 \\
\hline & KLV & 18.52 & 16.67 & 1 & 0 & 0 & 86.67 & 50.00 & 2 & 6 & 0 & 100 & 88.89 & 14 & 2 & 0 \\
\hline \multirow[t]{3}{*}{ Todo el An̆o } & $\mathrm{HF}$ & 80.00 & 35.97 & 7 & 34 & 0 & 98.44 & 62.50 & 0 & 43 & 0 & 98.18 & 70.18 & 25 & 6 & 9 \\
\hline & $\mathrm{VF}$ & 85.00 & 34.04 & 3 & 11 & 0 & 75.00 & 60.00 & 4 & 4 & 1 & 95.00 & 100.00 & 11 & 7 & 4 \\
\hline & KLV & 85.00 & 43.48 & 7 & 13 & 0 & 100.00 & 60.68 & 24 & 39 & 0 & 92.75 & 92.24 & 86 & 15 & 5 \\
\hline \multirow[t]{2}{*}{ Lisbon } & $\mathrm{VF}$ & 45.00 & 0.00 & 0 & 0 & 0 & 53.33 & 20.00 & 0 & 2 & 0 & 93.33 & 98.11 & 40 & 10 & 2 \\
\hline & KLV & 69.23 & 66.66 & 6 & 6 & 0 & 77.77 & 86.21 & 10 & 13 & 1 & 57.14 & 75.00 & 0 & 3 & 1 \\
\hline \multirow[t]{2}{*}{ Limoneria 8A Lisbon } & $\mathrm{HF}$ & 43.75 & 9.52 & 0 & 2 & 0 & 68.75 & 63.64 & 2 & 5 & 0 & 100.00 & 100.00 & 9 & 6 & 3 \\
\hline & VRL & 42.10 & 62.50 & 4 & 1 & 0 & 36.36 & 50.00 & 0 & 2 & 0 & 100.00 & 85.71 & 4 & 2 & 6 \\
\hline
\end{tabular}

${ }^{2}$ Tetraploid male progenitors: HF $=$ 'Hamlin' sweet orange $\times$ 'Femminello' lemon; KLV = 'Key' lime $\times$ 'Valencia' sweet orange; VF $=$ 'Valencia' sweet orange $\times$ 'Femminello' lemon; VRL = 'Valencia' sweet orange $\times$ rough lemon.

yPercentage of germinated embryos per embryo developmental stage.

xPercentage of germinated embryos that developed into complete plants.

$\mathrm{w}, \mathrm{v}, \mathrm{uPloidy}$ level: diploid, triploid, and tetraploid, respectively.

of KLV pollen viability was related with considerably higher fruit set and seed number per fruit in lemons (Lisbon and Todo el Año) (Table 3). Pollen of VF induced high fruit set in 'Lisbon' and 'Todo el Año', however about half of the total seed (53\%) were empty.

The five lemon varieties grown in Arizona performed differently. 'Limonero fino 49 ' is a very seedy variety that showed the highest fertility in all crosses, excluding the cross with VF (Table 3). 'Limoneria 8A Lisbon', 'Femminello Santa Teresa', and 'Genova' did not set fruit when the pollen progenitor was either VF or KLV. Unlike the others, 'Arancino' set some fruit from three different pollen parents; however, all of them lacked seeds. In general, most of the lemon parents developed high numbers of empty seeds, which could reach $\approx 50 \%$ of the total, or even higher in the case of 'Limonero fino 49' (60\% to 69\%), except 'Genova' $\times$ VRL.

The number of triploids generated in 2001 was noticeably high in all seed progenitors except 'Key' lime (12), Palestine sweet lime (6), and 'Etrog' citron (5) (Table 2). The frequency of triploids based on seed number was $5.5 \%, 24.0 \%$, and $1.1 \%$, respectively. 'Lakeland' limequat produced an increased amount of triploids (16) and doubled the percentage of recovered hybrids (7.9\%). All lemon fertile crosses developed high numbers of triploids per seed parent as follows: 34 'Lisbon', 172 'Todo el Año', 18 'Limoneria 8A Lisbon', 69 'Limonero Fino 49', and
14 'Femminello Santa Teresa' (Table 4). The corresponding triploid proportions were $9.5 \%, 20.4 \%, 7.9 \%, 7.6 \%$, and $16.9 \%$, respectively. An exception was the 'Genova' $\times$ VRL cross that generated only one hybrid.

The frequency of triploid production based on the pollen parent was also higher in the second season; $14.4 \%, 16.4 \%, 9.6 \%$, and $9.6 \%$ for HF, KLV, VF, and VRL, respectively, in lemon crosses. Lower percentages for $\mathrm{HF}(3.9 \%)$ and $\operatorname{VF}(2.7 \%)$ were observed in the other acid citrus seed parents, while KLV was similar(15.4\%). Unlike the first season, a high frequency of triploid lemon hybrids developed from mature cotyledonary embryos. Also, numerous tetraploids were obtained from fully developed seeds of 'Todo el Año' and 'Limonero Fino 49'. The other lemon parents also gave rise to tetraploids except 'Genova'.

In tetraploid $\times$ diploid crosses performed in 2000 and 2001, HF and VF as seed progenitors brought about very different results in relation to their reciprocals. It was only possible to harvest a few fruit from HF, with small seed numbers (Table 5). As in diploid $\times$ tetraploid crosses, fruit set, seed per fruit, and empty seed were affected in large extent by the pollen parents. Although fruit set increased for 'Key' lime and 'Lakeland' limequat in the second season, triploids were only obtained in the first season (Table 6). All fruit prematurely fell off cross-pollinated VF trees; however, when VF was the pollen parent, hybrids were recovered from 4 out of 11 cross combinations. Likewise, VRL was very 
Table 5. Fruit set, number of seeds and embryos obtained from tetraploid (somatic hybrid females) $\times$ diploid crosses conducted during the 2000 and 2001 seasons.

\begin{tabular}{|c|c|c|c|c|c|c|c|c|c|c|c|c|c|c|}
\hline \multirow{2}{*}{\multicolumn{2}{|c|}{ Progenitors }} & & & & & \multicolumn{9}{|c|}{ Seed (no.) } \\
\hline & & & & & & & Small & & & Medium & & & Large & \\
\hline & & \multicolumn{2}{|c|}{ Number } & \multirow{2}{*}{$\begin{array}{c}\text { Fruit Set } \\
(\%)\end{array}$} & \multirow{2}{*}{$\begin{array}{l}\text { Seeds/ } \\
\text { Fruit }\end{array}$} & \multirow{2}{*}{$\begin{array}{l}\text { Total } \\
\text { Seed }\end{array}$} & \multirow[b]{2}{*}{ Embryo } & \multirow[b]{2}{*}{ Empty } & \multirow{2}{*}{$\begin{array}{l}\text { Total } \\
\text { Seed }\end{array}$} & \multirow[b]{2}{*}{ Embryo } & \multirow[b]{2}{*}{ Empty } & \multicolumn{2}{|l|}{ Total } & \multirow[b]{2}{*}{ Empty } \\
\hline Seed $^{2}$ & Pollen & Flowers & Fruit & & & & & & & & & Seed & Embryo & \\
\hline \multirow[t]{3}{*}{ VRL } & Key lime & 70 & 0 & 0 & & & & & & & & 0 & 0 & 0 \\
\hline & Lakeland limequat & 79 & 0 & 0 & & & & & & & & 0 & 0 & 0 \\
\hline & Palestine sweet lime & 16 & 0 & 0 & & & & & & & & 0 & 0 & 0 \\
\hline \multirow[t]{3}{*}{$\mathrm{HF}$} & Key lime & 58 & 2 & 3.5 & & & & & & & & 4 & 0 & 0 \\
\hline & Lakeland limequat & 71 & 3 & 4.2 & & & & & & & & 11 & 0 & 0 \\
\hline & Palestine sweet lime & 5 & 1 & 20.0 & & & & & & & & 7 & 0 & 0 \\
\hline \multirow[t]{2}{*}{$\mathrm{HF}$} & Key lime & 48 & 5 & 10.4 & 4.2 & 11 & 3 & 9 & 9 & 9 & 0 & & & \\
\hline & Lakeland limequat & 38 & 3 & 7.9 & 2.3 & 2 & 1 & 1 & 5 & 4 & 1 & & & \\
\hline \multirow[t]{2}{*}{ VF } & Key lime & 33 & 0 & 0 & 0 & 0 & 0 & 0 & 0 & 0 & 0 & & & \\
\hline & Lakeland limequat & 21 & 0 & 0 & 0 & 0 & 0 & 0 & 0 & 0 & 0 & & & \\
\hline \multirow[t]{2}{*}{ VRL } & Key lime & 22 & 0 & 0 & 0 & 0 & 0 & 0 & 0 & 0 & 0 & & & \\
\hline & Lakeland limequat & 42 & 0 & 0 & 0 & 0 & 0 & 0 & 0 & 0 & 0 & & & \\
\hline
\end{tabular}

zTetraploid somatic hybrid female: VRL = 'Valencia' sweet orange $\times$ rough lemon; HF = 'Hamlin' sweet orange $\times$ 'Femminello' lemon; VF $=$ 'Valencia' sweet orange $\times$ 'Femminello' lemon.

If blank, no data available.

Table 6. Plant recovery and ploidy level of citrus progenies generated from tetraploid (somatic hybrid females) $\times$ diploid crosses completed in the 2000 and 2001 season.

\begin{tabular}{|c|c|c|c|c|c|c|c|c|c|c|c|c|c|}
\hline \multirow{2}{*}{\multicolumn{2}{|c|}{ Progenitors }} & \multicolumn{12}{|c|}{ Embryo Developmental Stage } \\
\hline & & \multicolumn{4}{|c|}{ Globular--Early Cotyledonary } & \multicolumn{4}{|c|}{ Immature Cotyledonary } & \multicolumn{4}{|c|}{ Mature Cotyledonary } \\
\hline $\operatorname{Seed}^{\mathrm{z}}$ & Pollen & $\% \mathrm{G}^{\mathrm{y}}$ & $\% \mathrm{NP}^{\mathrm{x}}$ & $3 X^{\mathrm{w}}$ & $4 X^{v}$ & $\% \mathrm{G}$ & $\% \mathrm{NP}$ & $3 \mathrm{X}$ & $4 \mathrm{X}$ & $\% \mathrm{G}$ & $\% \mathrm{NP}$ & $3 \mathrm{X}$ & $4 \mathrm{X}$ \\
\hline \multirow[t]{3}{*}{ VRL } & Key lime & & & & & & & & & 0 & 0 & 0 & 0 \\
\hline & Lakeland limequat & & & & & & & & & 0 & 0 & 0 & 0 \\
\hline & Palestine sweet lime & & & & & & & & & 0 & 0 & 0 & 0 \\
\hline \multirow[t]{3}{*}{$\mathrm{HF}$} & Key lime & & & & & & & & & 100 & 73.3 & 1 & 10 \\
\hline & Lakeland limequat & & & & & & & & & 100 & 90.0 & 5 & 40 \\
\hline & Palestine sweet lime & & & & & & & & & 100 & 60.5 & 0 & 23 \\
\hline \multirow[t]{2}{*}{$\mathrm{HF}$} & Key lime & 92.3 & 100 & 0 & 10 & 100 & 87.5 & 0 & 14 & & & & \\
\hline & Lakeland limequat & 100 & 91.0 & 0 & 10 & 100 & 100 & 0 & 41 & & & & \\
\hline \multirow[t]{2}{*}{$\mathrm{VF}$} & Key lime & 0 & 0 & 0 & 0 & 0 & 0 & 0 & 0 & & & & \\
\hline & Lakeland limequat & 0 & 0 & 0 & 0 & 0 & 0 & 0 & 0 & & & & \\
\hline \multirow[t]{2}{*}{ VRL } & Key lime & 0 & 0 & 0 & 0 & 0 & 0 & 0 & 0 & & & & \\
\hline & Lakeland limequat & 0 & 0 & 0 & 0 & 0 & 0 & 0 & 0 & & & & \\
\hline
\end{tabular}

zTetraploid somatic hybrid female: VRL = 'Valencia' sweet orange $\times$ rough lemon; HF = 'Hamlin' sweet orange $\times$ 'Femminello' lemon; $\mathrm{VF}=$ 'Valencia' sweet orange $\times$ 'Femminello' lemon.

yPercentage of germinated embryos per developmental stage.

xercentage of germinated embryos that developed into complete plants.

wvPloidy level: triploid and tetraploid, respectively.

If blank, no data available. 
incompetent as a seed progenitor, since no fruit was obtained in the 2000 and 2001 seasons, from three different crosses carried out on five plants grown in two locations. On the contrary, VRL as a pollen parent produced fertile crosses with 'Limoneria 8A Lisbon', 'Limonero Fino 49', and to a lesser extent with 'Genova', excluding 'Arancino' and 'Femminello Santa Teresa'.

In 2002, 'Todo el Año' $\times$ HF did not show a remarkable difference in fruit set, but the number of seed per fruit was considerably larger than the two previous seasons. 'Lisbon' lemon had better fruit set compared to the first season, and a similar number of seed per fruit (Table 3). The proportion of empty seed was also high (51\% to 59\%). Triploids were identified for all embryo stages, but 'Todo el Año' showed the highest cross fertility (Table 4). Similar to preceding seasons, tetraploids developed from large immature cotyledonary and mature cotyledonary embryos, with a larger number for 'Todo el Año'.

\section{Discussion}

In spite of the polyembryonic character of the female progenitors, polyploid hybrids were recovered from all progenitors except 'Arancino'. In citrus interploid hybridization, sexual tetraploids are recommended as seed parents instead of partly apomictic tetraploids and diploids, since a high proportion of triploids can be generated (Cameron and Burnett, 1978). In this study, very few hybrids were obtained only from HF allotetraploid somatic hybrid as the seed progenitor. HF is highly polyembryonic; a maximum of 10 embryos per seed was recorded. However, a major limitation was the poor fruit set from all allotetraploid somatic hybrids tested as seed progenitors in this study. It is likely that factors related with fertilization and ploidy ratio affected fruit set of controlled pollinations, since fruit developed from open pollinated flowers. Lower fruit set and seed number were reported for autotetraploid mandarins in tetraploid $\times$ diploid crosses as compared to their reciprocals (Khan et al., 1996). Generally, allotetraploid somatic hybrids are used as citrus pollen progenitors (Deng et al., 1996; Oiyama et al., 1991; Tusa et al., 1996), rather than female progenitors. This preference may be related with the polyembryonic character of somatic hybrids.

Although, zygotic embryos are more likely to be present in small seeds, a high proportion of small-germinated embryos did not develop into normal plants. Perhaps the tested media did not meet the embryo requirements for complete development, considering that embryo development is a dynamic system that continually changes during maturation (Ramming, 1990). Another factor that cannot be disregarded is the presence of aneuploids in the new hybrids. Esen and Soost (1972a) determined that most frequent viable aneuploids were $3 \mathrm{X}+1=28(24.8 \%)$ and $4 \mathrm{X}+1=37$ $(45.9 \%)$ in a seedling population from diploid $\times$ tetraploid crosses. They also found a wide range of aneuploid chromosome numbers in developing embryos (22-41 chromosomes). It was suggested that the number of extra or absent chromosomes, as well as the type of information stored in the extra or missing chromosomes, may affect the plant viability and vigor. Aneuploidy could have also been present in rescued embryos with very low vigor.

'Key' lime and 'Lakeland' limequat as seed progenitors showed low cross fertility; many fruit dropped off the trees during the first 2 weeks after pollination and small frequencies of hybrids were recovered from different crosses. These progenitors also had a low number of viable seed per fruit, with two to three embryos per seed. In the second season, more immature embryos were obtained from both seed parents by reducing the harvest time to 60 $\mathrm{d}$ after pollination instead of 3 months. Unexpectedly, some 'Key' lime fruit lacked seeds or contained a few in the second season. Palestine sweet lime showed low fertility in the first season, but higher triploid frequency was recorded from the viable crosses in 2001. In open-pollinated seedlings, sampling year and variety influenced the frequency of zygotic vs. nucellar embryos. Crop load, plant age, and nutrient status might also affect the frequency of zygotic embryos and the difference observed among seasons (Khan and Roose, 1988). The inappropriate climatic conditions for the tropical progenitors may have also played a significant role on the lower number of triploid hybrid production from those progenitors. 'Etrog' citron is a very seedy variety (approximately 117 seeds/open-pollinated fruit), nonetheless the success of triploid production was limited owing to the fast development of single diploid embryos in most of the seed.

Most of the lemon varieties showed high fertility in diploid $\times$ tetraploid crosses. Also, immature lemon embryos germinated more efficiently in vitro, giving rise to a high number of normal triploids. Lemon triploid production was also favored by the large numbers of seeds. Despite the high proportion of empty seeds, particularly 'Limonero Fino 49' (60\% to 69\%) and 'Limoneria 8 A Lisbon' ( $53 \%)$, high numbers of viable seeds were obtained. The less seedy lemons ('Genova' and 'Femminello Santa Teresa') had a low proportion of empty seeds. In lemons, most of the small empty seeds were indeed ovules whose embryos aborted at a very early stage. Ovules were very small without any visible remnants of embryo or endosperm. Esen and Soost (1971) determined that partial and fully developed seeds arise from fertilized ovules.

The VF somatic hybrid showed the lowest sexual compatibility with most of the seed parents. Despite its high pollen viability, hybrids were only recovered from crosses with 'Key' lime, 'Lakeland' limequat, and the 'Todo el Año' and 'Lisbon' lemons; the other seed parents did not set fruit at all, except 'Arancino', but the fruit were seedless. 'Etrog' citron $\times$ VF also showed sexual incompatibility that brought about very low number of viable seeds and large amount of empty seeds, which was a different outcome with respect to the other 'Etrog' citron crosses. Several factors besides the sexual compatibility and embryo-endosperm ploidy ratio, such as embryo rescue technique, pollen viability, agronomic practices, and climatic conditions might have influenced the generation of triploid citrus hybrids in this study.

The high frequency of tetraploid seedlings obtained from fully developed seeds was rather consistent in lemon progenitors, with a very low incidence in 'Key' lime and 'Lakeland' limequat, and totally absent in the other seed progenitors. Similarly, Tusa et al. (1996) reported a high proportion of tetraploids in progenies from diploid $\times$ tetraploid crosses using the polyembryonic 'Femminello' lemon as female parent. Studies on citrus seed development from monoembryonic diploid $\times$ tetraploid crosses demonstrated that seeds with a tetraploid embryo and hexaploid endosperm develop normally. A remarkable difference was observed between the developmental stages of triploids and tetraploids; tetraploid embryos were larger and more advanced in development in relation to triploids (Essen and Soost, 1973), which is comparable to results reported here for lemon triploid and tetraploid embryos.

In monoembryonic seed progenitors, the hybrids were often tetraploid in diploid $\times$ tetraploid crosses (Cameron and Soost, 1969). It was proven that tetraploid seedlings originated from fertilization of unreduced gametes of monoembryonic diploid female parents (Essen and Soost, 1972b). Spontaneous tetraploids developing from nucellar tissue have also been reported in citrus (Soost and Roose, 1996). Tetraploid hybrids and spontaneous 
autotetraploids were also identified in mandarin progenies obtained from polyembryonic seed parents in diploid $\times$ tetraploid crosses (Kaneyoshi et al., 1997). In any case, it is necessary to confirm the origin of those tetraploids to judge their significance. Tetraploid hybrid progenies would increase the genetic variability and availability of breeding parents for interploid hybridization. Pentaploid and hexaploid seedlings were weak and, therefore, no normal plants were recovered. Weak pentaploids were also identified in progenies generated from diploid $\times$ diploid crosses (Oiyama and Kobayashi, 1991).

In this study, a genetically diverse population of acid citrus fruit triploids has been generated to provide a pool of genetic variability for further horticultural evaluation and selection of seedless varieties with improved traits including disease resistance and cold-hardiness. The unique genomic composition of the allotetraploid somatic hybrids and degree of compatibility with the acid citrus fruit varieties selected, confirmed their potential as pollen parents. Furthermore, the genomes of the selected somatic hybrids contain half of either lemon or lime genetic composition; therefore, they have potential to produce new seedless acid citrus fruit progenies with more cold-hardiness and disease resistance (Tusa et al., 2000).

Progenies from interploid hybridization also posses a high potential for improved oil quality and content in correspondence with previous reports for lemon triploid hybrids (Gazea et al., 1996; Ruberto et al., 1997) and the allotetraploid somatic hybrid 'Valencia' sweet orange $\times$ 'Femminello' lemon (Fatta del Bosco et al., 1998). It was also established that fruit of triploid lemons had high acid percentages; however, this variable was affected by cross direction (Soost and Cameron, 1969). Selected progenies from this study have been examined for oil quality on a limited basis, and quantitative and qualitative changes in oil components have been observed (R. Rouseff, personal communication).

Ornamental use of citrus trees has been underexploited. Citrus and citrus relatives are suitable for landscaping and different ornamental uses, according to an Italian study about the potential use of citrus as ornamentals (Continella et al., 1992). New progenies from this study showing a compact growth habit and attractive foliage may have value as dooryard trees or ornamentals.

The application of embryo rescue technology following interploid hybridization allowed the recovery of numerous triploid acid citrus fruit progenies. All triploid and allotetraploid progeny recovered from this study have been grafted to rootstocks in preparation for field evaluation. Hybrids containing 'Lakeland' limequat germplasm are being evaluated for potential canker resistance, and a few resistant hybrids have already been identified (Viloria et al., 2004). Information generated from this study should be useful in designing future acid citrus fruit breeding experiments, especially regarding parental selection.

\section{Literature Cited}

Cameron, J.W. and R.H. Burnett. 1978. Use of sexual tetraploid seed parents for production of triploid Citrus hybrids. HortScience 13:167-169.

Cameron, J.W. and R.K. Soost. 1969. Characters of new populations of Citrus polyploids and the relation between tetraploidy in the pollen parent and hybrid tetraploid progeny. Proc. First Intl. Citrus Symp. 1:199-205.

Carputo, D., L. Monti, J.E. Werner, and L. Frusciante. 1999. Uses and usefulness of endosperm balance number. Theor. Appl. Genet. 98:478-484.
Continella G., G. La Malfa, and D. Romano. 1992. The utilization of citrus as ornamental plants in Italy. Proc. Intl. Soc. Citriculture. $1: 232-234$.

Deng, ×.x., H.L. Yi, F. Li, and W.W. Guo. 1996. Triploid plants regenerated from crossing diploid pummelo and tangerine with allotetraploid somatic hybrid of citrus. Proc. Intl. Soc. Citriculture. 1:189-192.

Esen, A. and R.K. Soost. 1971. Unexpected triploid in Citrus : Their origin, identification and possible use. J. Hered. 62:329-333.

Esen, A. and R.K. Soost. 1972a. Aneuplody in citrus. Amer. J. Bot. 59:473-477.

Esen, A. and R.K. Soost. 1972b. Tetraploid progenies from $2 \mathrm{X} \times 4 \mathrm{X}$ crosses of citrus and their origin. HortScience 97:410-414.

Esen, A. and R.K. Soost. 1973. Seed development in citrus with special reference to $2 \mathrm{X} \times 4 \mathrm{X}$ crosses. Amer. J. Bot. 60: 448-462.

Fatta del Bosco, S., E. Palazzolo, M.T. Scarano, M.A. Germana, and N. Tusa. 1998. Comparison between essential oil yield and constituents of an allotetraploid somatic hybrid of Citrus and its parents. Adv. Hort. Sci. 12:72-77.

Florida Department of Agriculture. 2001. Citrus summary 1999-00. Florida Agr. Stat. Serv., Orlando.

Florida Department of Agriculture. 2002. Tropical fruit, acres and trees; 2002. 19 Feb. 2003. <http://www.nass.usda.gov/fl/rtoc0ci.htm>.

Gazea, F., I. Calvarano, M. Calvarano, G. Russo, and A. Starrantino. 1996. Essential oil composition of a triploid lemon hybrid. Proc. Intl. Soc. Citricult. 1:331-333.

Grosser, J.W. and F.G. Gmitter, Jr. 1990. Protoplast fusion and citrus improvement. Plant Breed. Rev. 8:339-374.

Grosser, J.W., J. Jiang, F.A.A. Mourao-Fo, E.S. Louzada, K. Baergen, J.L. Chandler, and F.G. Gmitter Jr. 1998. Somatic hybridization, an integral component of citrus cultivar improvement: I. Scion improvement. HortScience 33:1057-1059.

Grosser, J.W., P. Ollitrault, and O. Olivares-Fuster. 2000. Somatic hybridization in citrus: an effective tool to facilitate variety improvement. In vitro Cellular Develop. Biol. 36:434-449.

Gulsen, O. and M.L. Roose. 2001. Chloroplast and nuclear genome analysis of the parentage of lemons. J. Amer. Soc. Hort. Sci. 126:210-215.

Guo, W.W., D. Prasad, Y.J. Cheng, P. Serrano, X.X. Deng, and J.W. Grosser. 2004. Targeted cybridization in citrus: transfer of Satsuma cytoplasm to seedy cultivars for potential seedlessness. Plant Cell Rpt. 22:752-758.

Kaneyoshi, J., T. Kanou, Y. Kuwata, A. Hirao, S. Nakatani, and S. Kobayashi. 1997. Breeding of triploid citrus cultivars: I. Production of triploids from Satsuma mandarin (Citrus unshiu Marc.) $\times$ tetraploid Ponkan mandarin (Citrus reticulata Blanco) crosses. J. Jpn. Soc. Hort. Sci. 66:9-14. (Abstr.)

Khan, I.A. and M.L. Roose. 1988. Frequency and characteristics of nucellar and zygotic seedlings in three cultivars of trifoliate orange. J. Amer. Soc. Hort. Sci. 113:105-110.

Khan, I.A., M.J. Jaskani, and S.N.H. Ali. 1996. Interploid hybridization for the improvement of Kinnow mandarin. Proc. Intl. Soc. Citricult. 137-140.

Knorr, L.C. 1958. Finding the best lemon in Florida-A progress report. Proc. Fla. State Hort. Soc. 71:124-146.

Medina-Urrutia, V., K. Fabiola Lopez Madera, P. Serrano, G. Ananthakrishnan, W.W. Guo, and J.W. Grosser. 2004. New intergeneric somatic hybrids combining Amblycarpa mandarin with six trifoliate/trifoliate hybrid selections for lime rootstock improvement. HortScience 39:355-360.

Murashige, T. and F.M., Skoog. 1962. A Revised medium for rapid growth and bioassays with tobacco tissue cultures. Physiol. Planta. 15:473-497.

Nicolosi, E., Z.N. Deng, A. Gentile, S. La Malfa, G. Continella, and E. Tribulato. 2000. Citrus phylogeny and genetic origin of important species as investigated by molecular markers. Theor. Appl. Genet. 100:1155-1166.

Oiyama, I. and S. Kobayashi. 1990. Polyembryony in undeveloped monoembryonic diploid seeds crossed with citrus tetraploid. HortScience 25:1276-1277. 
Oiyama I., and S. Kobayashi. 1991. Citrus pentaploids from small seeds of diploid $\times$ diploid crosses. HortScience 26:292-293.

Oiyama, I., S. Kobayashi, K. Yoshinaga, T. Ohgawara, and S. Ishii. 1991. Use of pollen from somatic hybrids between Citrus and Poncirus in the production of triploids. HortScience 26:1082.

Ramming, D.W. 1990. The use of embryo culture in fruit breeding. HortScience 25:393-398.

Roose, M.L. and T.E. Williams. 2000. Citrus scion breeding in California. Proc. Intl. Soc. Citricult. I:34-36.

Ruberto, G., A. Renda, M. Piattelli,P. Rapisarda, and A. Starrantino. 1997. Essential oil of two new pigmented citrus hybrids Citrus clementina $\times$ Citrus sinensis. J. Agr. Food Chem. 45:467-471.

Soares Filho, W.S., J.E. Vasquez, M.A.P. da Cunha, A.P. da Cunha Sobrinho, and O.S. Passos. 1992. Degree of polyembryony, size and survival of the zygotic embryo in citrus. Proc. Intl. Soc. Citricult. $1: 135-138$.

Soost, R.K. and J.W. Cameron. 1969. Tree and fruit characters of Citrus triploids from tetraploid by diploid crosses. Hilgardia 39:569-579.
Soost, R.K. and M. Roose. 1996. Citrus, p. 257-323. In: J. Jules and J. N. Moore (eds.). Fruit breeding: Tree and tropical fruits. Wiley, New York.

Starrantino, A. 1992. Use of triploids for production of seedless cultivars in Citrus improvement programs. Proc. Intl. Soc. Citricult. $1: 117-121$.

Tusa, N., S. Fatta del Bosco, L. Nardi, and S. Lucretti. 1996. Obtaining triploid plants by crossing citrus lemon cv. 'Femminello' $2 \mathrm{~N} \times 4 \mathrm{~N}$ allotetraploid somatic hybrids. Proc. Intl. Soc. Citricult. 1:133-136.

Tusa, N., S. Fatta del Bosco, F. Nigro, and A. Ippolito. 2000. Response of cybrids and a somatic hybrid of lemon to Phoma tracheiphila infections. HortScience 35:125-127.

Viloria,Z., D. Droulliard, J.H. Graham, and J.W. Grosser. 2004. Screening triploid hybrids of "Lakeland" limequat for resistance to citrus canker. Plant Dis. 88:1056-1060.

Wakana, A., M. Iwamasa, and S. Uemoto. 1981. Seed development in relation to ploidy of zygotic embryo and endosperm in polyembryonic citrus. Proc. Intl. Soc. Citricult. 1:35-39. 